Man and Nature

MAN AND NATURE

L'homme et la nature

L'HOMME ET LA NATURE

\title{
J.K. Wezel's Views of Society in his Novel Herrmann und Ulrike and Rousseau's La Nouvelle Héloise
}

\section{Albert R. Schmitt}

Volume 11, 1992

URI : https://id.erudit.org/iderudit/1012678ar

DOI : https://doi.org/10.7202/1012678ar

Aller au sommaire du numéro

Éditeur(s)

Canadian Society for Eighteenth-Century Studies / Société canadienne d'étude du dix-huitième siècle

ISSN

0824-3298 (imprimé)

1927-8810 (numérique)

Découvrir la revue

Citer cet article

Schmitt, A. R. (1992). J.K. Wezel's Views of Society in his Novel Herrmann und Ulrike and Rousseau's La Nouvelle Héloise. Man and Nature / L'homme et la nature, 11, 139-150. https://doi.org/10.7202/1012678ar

Copyright (c) Canadian Society for Eighteenth-Century Studies / Sociéte canadienne d'étude du dix-huitième siècle, 1992
Ce document est protégé par la loi sur le droit d'auteur. L'utilisation des services d'Érudit (y compris la reproduction) est assujettie à sa politique d'utilisation que vous pouvez consulter en ligne.

https://apropos.erudit.org/fr/usagers/politique-dutilisation/ 


\section{J.K. Wezel's Views of Society in his Novel Herrmann und Ulrike and Rousseau's La Nouvelle Héloise}

Johann Karl Wezel (1747-1819) was a rebel on the German literary scene during the mere fourteen years of his publishing career which covered the period of 1772 to 1785 . Although he certainly made a name for himself as a novelist, writer of comedies, literary critic, and philosopher, he has yet to be admitted to the canon of literary history ${ }^{1}$ for reasons known, for the most part, only to a relatively small circle of aficionados. He was an uncomprising social critic, a keen and, in the eyes of quite a few contemporary writers, merciless judge of human nature, and an enemy of Leibniz' philosophy of optimism, a position considered to be almost sacrilegious by many at the time. Wezel preferred the skepticism of Thomas Hobbes, the empiricism of John Locke, and the views of French materialists. In his devastating review of Wieland's Oberon in 1781, he left no doubt that to him a 'realistic' writer is certainly to be preferred to an 'idealistic' one. ${ }^{2}$ It is more than likely that Wezel would have agreed with the concluding line from Günter Eich's poem 'Wacht auf, denn eure Träume sind schlecht':

Seid unbequem, seid Sand, nicht das Öl im Getriebe der Welt ${ }^{3}$

Wezel's writings satisfy the demand Siegfried Lenz made in his speech 'Der Künstler als Mitwisser' (1962):

Mein Anspruch an den Schriftsteller besteht nicht darin, daß er, verschont von der Welt, mit einer Schere schöne Dinge aus Silberpapier schneidet; vielmehr hoffe ich, daß er mit dem Mittel der Sprache den Augenblicken unserer Verzweiflung und den Augenblicken eines schwierigen Glücks Widerhall verschafft. In unserer Welt wird auch der Künstler zum Mitwisser - zum Mitwisser von Rechtlosigkeit, von Hunger, von Verfolgung und riskanten Träumen.... ${ }^{4}$ 
It is attitudes like these, and an uncompromisingly realistic way of observing people as well as social institutions that we have to keep in mind when we compare certain aspects of Rousseau's Nouvelle Héloise with Wezel's Herrmann und Ulrike.

A quick look back at the literary scene in Germany during the 1770 s and early 1780s will remind us of the highly significant influence Rousseau had on the literary upheaval and development in Germany at that time. We can probably agree that the entire Sturm-und-Drang movement is - next to Shakespeare's - the direct result of Rousseau's effect on the generation born in the 1740s and 1750s. Tired of the fetters of reason and rules in life and in the arts, the young generation took to Rousseau's cultural pessimism, his criticism of corruption and excessive luxury in society and particularly in courtly circles, the way fish take to water. His call for simplicity, a natural way of life, and his revolutionary views on education helped form some of the strongest roots of the Sturm-undDrang movement. Without him, Faust's introductory monologue may have been written differently, and Schiller's Räuber Moor might not have been quite as nauseated by his 'tintenklecksendes Säkulum.' Let us not forget that Rousseau went by the epithet of 'göttlicher Jean-Jacques' despite his often inconsistent and even contradictory views and notions.

In 1779 , shortly after Rousseau's death, Helfrich Peter Sturz wrote his 'Denkwürdigkeiten von Johann Jacob Rousseau.' The essay was published in Leipzig (where Wezel lived at the time) by the well-known publishing house of Weidmanns Erben und Reich, and enjoyed a great deal of popularity. It was nothing short of a eulogy of the deceased. Toward the end of his essay Sturz declares: 'Alle, die ihn kannten, geben ihm das einmütige Zeugniß, daß er die Wahrheit ernstlich suchte, daß er von dem Satz, den er jedes Mal lehrte, durchdrungen war, daß er nicht glänzen, sondern überzeugen, keine Secte stiften, sondern bessern wollte.' Yet Sturz also asks:

Aber war nicht Rousseau ein Träumer? hat er seine Zeit, hat er die Menschen gekannt? lebte und webte er nicht in einer idealischen Welt? fordert er nicht zu viel von dem verdorbenen Geschlecht? ist sein Vorbild der Tugend und Weisheit nicht aus der Halbgötter Zeit? Es kann seyn; gleichwohl ist es ein ehrwürdiger Traum, uns Thätigkeit, Gefühl unsers Wohls, und Trotz auf unsere Rechte zuzutrauen. ${ }^{5}$

La Nouvelle Héloise first appeared in France in 1761. It was translated into German that same year by J.G. Gellius under the title Die Neue Héloise, oder Briefe zweyer Liebenden aus einer kleinen Stadt am Fuße der Alpen, and published in Leipzig by the above mentioned Weidmanns 
Erben und Reich. In the following year, 1762, Rousseau published Emile, ou de l'Education, and it also appeared in German translation that very year, again attesting to the author's popularity east of the Rhine.

To the best of my knowledge, Wezel makes reference to Rousseau by name only three times. The first mention appears in a letter to his friend and mentor, the poet C.F. Gellert, in whose house he had lived during his student days in Leipzig. The letter is dated May 25, 1769. Writing about his employer, Johann Wilhelm Traugott von Schönberg in Bautzen (where, from 1769 to 1774, he was Hofmeister to Schönberg's two sons), Wezel remarks: 'Seine [Schönberg's] Liebe zu dem Rousseau ist so groß, daß er sich sogar hat verleiten lassen, an seinen Kindern einen Versuch zu machen, ob Arbeits-Erziehung eine Grille sei.' Following Rousseau's recommendation, Schönberg had his sons learn to work with their hands at the expense of book learning. Wezel, apparently not quite in agreement with that educational policy, concludes that, fortunately, the boys had 'alle große Gaben' to give him hope that through diligence 'das Versäumte wird eingebracht werden.'

Nine years later - Wezel meanwhile had kicked up quite a bit of dust in the literary establishment with the publication of his first two novels, Tobias Knaut and Belphegor, as well as with his Satirische Erzählungen he gave a detailed account of his thoughts on education in the journal Pädagogische Unterhandlungen published by the Dessau Philanthropinum or 'Dessauisches Erziehungs-Institut,' founded in 1774 by the educator Johann Bernhard Basedow, an enthusiastic follower of Rousseau's. Wezel considers traditional education which tries to transform human nature foolhardy and reckless: 'Ich glaube, daß wir dieser vorgeblichen Verbesserung der Natur einzig unsre Schurken und Heuchler zu verdanken haben. Die Natur zeugte nie einen Bösewicht: wer es ist, wurde es durch die Erziehung. ${ }^{17}$ Education, if it fails to recognize individuality, 'hebt ... die Verschiedenheit der Charaktere auf, und macht die Welt zu einem einförmigen langweiligen Garten. ${ }^{8}$ Such ideas led to the formation of another group of educators, who came to public attention under the guidance of Rousseau and Basedow. They found it to be more advantageous to the common good as well as to the individual, 'wenn man die Natur in jedem Zöglinge frey wirken ließ, ihn [sic] nachspürte, und nur durch kleine Hülfen hie und da zur Hand gienge, als Subjekt werden ließ, was es nach der Absicht der Natur werden zu sollen schien, und folglich nichts verbesserte, sondern alles entwickelte. ${ }^{9}$ However, this approach requires considerable psychological insight on the part of the educator, a great gift of observation of nature and individual character differences. Therefore, Wezel proposes to combine those two educational methodologies in order to bring about the advantages of both. This would necessitate finding 'erstlich das 
allgemeine Ideal der menschlichen Natur ... [whatever he means by that!], und dann zu überlegen, wie man jedes einzelne Subjekt diesem allgemeinen Ideal nähern könne, ohne seinen besondern Individualitäten Gewalt anzuthun. ${ }^{10}$ But then Wezel goes far beyond Rousseau and Basedow - which probably was the reason why he did not get the teaching position for which he had applied at the Philanthropinum by emphasizing the fact that each student has to be seen as a member of his environment, both politically and socially: 'Allgemeine Erziehung für die Welt, ohne Betrachtung der Zeit und des Orts, das heißt, der Staatsverfassung und des Nationalcharakters, wie ihn Natur und Schicksal bilden, ist Schimäre.... Bildung für die ganze Welt ist, wie allgemeine Menschenliebe, eine große Idee, wenn wir sie denken, und ein kleines Nichts, wenn wir sie ausführen wollen., ${ }^{11}$

The third mention of Rousseau aims at Emile, specifically the passage where the author suggests that Defoe's Robinson Crusoe be the first book to be read by young Emile. In view of his controversy over Joachim Heinrich Campes's Robinson der Jüngere $(1779 / 80)$ and the immediate popularity that work enjoyed, Wezel, in the preface to the second part of his own adaptation (1780) of Defoe's Robinson, wrote:

Wäre Rousseau ein schadenfroher Mann gewesen, so könnte seine Seele itzt ein köstliches Vergnügen genießen, wenn sie von dem Fixsterne, wo sie etwa wohnen mag, ${ }^{12}$ einen Blick auf Teutschland wärfe und die mannigfaltigen Bewegungen wahrnähme, die ein einziges Urteil [in Rousseaus Emile] über den Robinson unter Autorfedern, Druckerpressen, Verlegern, Herausgebern, Papierhändlern, Buchbindern, Rezensenten und vielleicht auch unter Lesern veranlaßt hat. ${ }^{13}$

Wezel is not sure to what extent all these people were tricked by the citizen of Geneva, but as far as he, Wezel, is concerned he can assure Rousseau, 'daß nichter mich zum April schickte, sondern ich selbst.' This remark is followed immediately by a statement which unequivocally demonstrates the fundamental difference between Wezel and Rousseau:

Ich habe mir bei allen Urteilen, Meinungen, Behauptungen, bei allem Lobe und Tadel dieses Mannes schon längst eine Subtraktion angewöhnt, die in jedem Falle Dreiviertel abzieht: der Rest ist Wahrheit. Daß er den innern Wert aller Sachen meistens durch einen so unmäßigen Zusatz veränderte, war niemals seine Schuld, sondern rührte offenbar von einem Betruge her, den ihm die Einbildung oder der Affekt spielte. ${ }^{14}$ 
This is, of course, reminiscent of Helfrich Peter Sturz calling Rousseau a 'Träumer,' and it brings to mind again Wezel's distinction between 'idealists' and 'realists' among writers, as he used it in his review of Wieland's Oberon.

Recent research, for example that of Phillip S. McKnight, Thilo Joerger, and Anneliese Klingenberg, ${ }^{15}$ along with earlier studies, concerns itself with the question of Wezel's reaction to views expressed by other writers of his time, as well as to contemporary philosophical and aesthetic concepts. It has been demonstrated convincingly that Wezel, not unlike his antagonist Wieland, was unusually receptive and sensitive to ideas he encountered in contemporary writing. Without ever becoming an imitator or even plagiarizer, he would use such ideas to react to, contradict, exaggerate, and satirize, especially whatever he considered to be unrealistically optimistic, idealistic, palliative, and acquiescing or hypocritical attitudes, basing his own works on uncompromising, realistic, and sharp-eyed observations of human nature and social institutions.

Thus Wezel's first novel, Lebensgeschichte Tobias Knauts ... (1773-1776) is, as Anneliese Klingenberg convincingly argues, the author's answer to Wieland's 'idealistic' novels Geschichte des Agathon and Don Sylvio von Rosalva. Wieland's heroes are members of the upper class, they are well-to-do, they live outside Germany and its social systems, they pursue Shaftesbury's concept of 'Kalokagathia,' and are themselves beautiful people. Their ultimate goal, in terms of the 18th century's belief in man's perfectibility, is to become wise and virtuous. Tobias Knaut also strives for 'Weisheit und Tugend,' yet, as Klingenberg points out, 'was sich ihm unter den Bedingungen der deutschen Ständeordnung unter diesen Namen anbietet, ist Deformation, körperliche, seelische und geistige Verkrüppelung, ist "Stammeln." Dabei richtet sich Wezels Kritik ... ebenso gegen die Umstände, die den Helden deformieren wie gegen den Helden, der sich der Deformation nicht erwehrt. ${ }^{16}$

In his second novel, Belphegor, oder die wahrscheinlichste Geschichte unter der Sonne (1776), Wezel, in the title, takes a swipe at Wieland's Die Abderiten, eine sehr wahrscheinliche Geschichte, which began appearing in his journal Der teutsche Merkur in $1774 .{ }^{17}$ But Wezel's point of departure was Voltaire's Candide, ${ }^{18}$ and he outdoes his source by demonstrating that human beings are constantly at war with each other, that life is nothing but a bellum omnium contra omnes, a war of all against all, which is the motto of the novel and borrowed from Thomas Hobbes. But where Voltaire merely, or even primarily, refutes Leibniz' idea of this being the best of all possible worlds, Wezel, as Thilo Joerger correctly puts it, intends to unveil as pernicious deception traditional views, especially among the bourgeoisie, propagating the idea of innate goodness and 
noble humanity in man. The bourgeois has to learn what life is really like if he wants to play an effective part in it. ${ }^{19}$

In his version of Robinson Krusoe (1779/80) Wezel takes utopianism to task. The new society that was established on Robinson's idyllic island ends in utter chaos. Wezel's last novel Wilhelmine Arend, oder die Gefahren der Empfindsamkeit (1782) takes issue not with a particular author or work but with the idea of exaggerated sentimentality, 'Empfindsamkeit,' that untranslatable German word which pervaded Europe during the second half of the 18th century. And in 1784 there appeared Wezel's Kakerlak, oder Geschichte eines Rosenkreuzers aus dem vorigen Jahrhunderte, a parodical treatment of 'Feenmärchen' such as Wieland's Oberon and of the Faust-theme, years before the general public was introduced to Goethe's Faust.

As far as I can judge, the main thrust of Wezel's literary output is one of pointing out the discrepancies between the 'ideal,' which exists primarily as a kind of escape mechanism or as a defense of the status quo, and the 'real,' which we have to learn to recognize, get to know, and master, in order to survive in this world.

These considerations led me to theorize - I cannot provide factual evidence - that Wezel's best known and most acclaimed novel Herrmann und Ulrike (1780) can, or perhaps should, be seen as his answer to Rousseau's epistolary novel Julie, ou la Nouvelle Héloise (1761). In Wezel's eyes, Rousseau, in this voluminous opus, must have violated just about every principle which he - Wezel - believed in. His own novel is by no means compact. It appeared in four volumes of 400 or more pages each. But what a wealth of action, reflection, description, character development, and diversity of form, when compared with Rousseau's constant over-emoting, moralizing, and preaching. Among the most outstanding characteristics of Rousseau's novel is his insistent demand for the pursuit of virtue as demonstrated so tiringly before him by Samuel Richardson in his Clarissa, Pamela, and Grandison. Human weakness, especially in the area of sexual behavior, must be atoned for through renunciation, resignation, and self-denial.

Apparently Rousseau saw this as progress in comparison to the fate that had befallen Abélard, the original Saint-Preux. Twice, Julie the young Baroness d'Etange, and her bourgeois tutor Saint Preux succumb to temptation and consummate their love. Punishment is swift and drastic. The pregnancy resulting from the second encounter is terminated by Julie's father, not intentionally, of course, when, in a fit of rage caused by his learning of her affair with Saint-Preux, he strikes her and she falls hitting a table leg, thus bringing on a miscarriage.

The barrier separating the nobility from the bourgeoisie must not be crossed or disregarded. Social convention as represented and defended, 
first by Julie's father, and later by her husband, M. de Wolmar, must be respected and maintained at all cost. While Julie vows never to leave the paternal household, her erstwhile lover Saint-Preux is exiled twice, once to Paris - giving Rousseau the opportunity to pass judgment as he so often does on the corruption of city life - and once on a sea voyage of four years' duration where he has a Crusoe-like experience on the island of Tinian, ${ }^{20}$ one of the utopias Rousseau creates in the novel.

Julie obeys her father by marrying M. de Wolmar, the man of her father's choice. Saint-Preux, upon learning of the event, falls into deep depression and contemplates suicide. Twenty-three years later, Werther, a kind of distant cousin, does end his life. Julie treasures her husband, his tenderness, serenity, and goodness - although he admits to being an atheist! - and she eventually becomes the mother of two sons. They live at de Wolmar's estate, Clarens, which represents Rousseau's ultimate social utopia. One of the least credible aspects of the novel, as far as human behavior is concerned, is de Wolmar's invitation to Saint-Preux to join him and his family, and to live with them at Clarens, although he is fully aware of the earlier relationship between his wife and her former tutor. Saint-Preux does accept the invitation and, resigned to their fate, they live together virtuously at Clarens, albeit not too happily. The former lovers cannot quite dismiss from their minds and hearts their past relationship and experiences.

Considering the fact that Rousseau is often hailed as one of the spirtual fathers of the French Revolution as a result of the emphasis he places on personal freedom, equality, and a simple and natural life style free of social corruption, it is astounding that he could seriously present as highly structured and thoroughly paternal, indeed patriarchal, an order as he does throughout the novel, but particularly at Clarens. In an unusually long letter - No. 10 in Part Four of the novel - Saint-Preux in detail describes life at Clarens to Milord Edouard. It is through the pen of Saint-Preux that Rousseau presents his views of society the way he would like it to be. There is the landlord, a benevolent despot, who handpicks his servants and day laborers - although in consultation with his wife - and instructs them in their everyday duties. The subordinates are not involved in any decision-making process; on the contrary, they are treated like children and have to follow strict daily routines ensuring that no outside influence, vice, or corruption enter this alpine seat of country innocence and virtue. Except for taking their meals together the two sexes have very little contact with one another because too much familiarity among male and female servants is seen as having nothing but detrimental consequences - shades of a slavery mentality? Julie is reported as saying that neither love nor marital bond necessitate constant contact among the sexes; male and female are destined to 
complement each other; while they have to agree in their actions, they do not perform the same duties because their natural inclinations are as different as the jobs they have to do, and their pleasures are as different as their duties. This distribution of labor and concerns is the strongest bond in their relationship. In short, Rousseau seems to want to force the real world through a funnel, as it were, in order to compress and channel it into a small and idyllic world where control can be exercised by a few over many. Was it really a slanderous tongue that called the virtuous Robespierre a prize disciple of Rousseau's?

In general, La Nouvelle Héloise may justly be called a 'Prüfungsroman,' a novel of tests and trials, rather than an 'Entwicklungsroman,' a developmental novel. The world of La Nouvelle Héloise is inhabited by static characters, who give no sign of having undergone any development, or even change.

This is precisely the opposite of what Wezel intended to achieve in Herrmann und Ulrike. From a small feudal principality ruled by an incompetent but megalomanic count and his equally insignificant wife (who, by the way, have remained childless), Wezel sends his main characters, Herrmann, the petit bourgeois, and Ulrike, the fatherless young baroness from an impoverished family, out into the world where, after many trials and errors, they grow and mature until they have learned that a person's worth in society depends on his/her inner strength and values rather than on being the member of a social class. Young Herrmann's parents were persuaded to let their son live at the court because Count and Countess von Ohlau had taken a fancy to the high spirited and bright boy. He and Ulrike, the Count's niece, were brought up together almost as equals, and eventually fell in love. No attempt to separate them, no matter how cunningly conceived, could destroy their love for each other. They are exiled, so to speak, to different parts of Germany in order to make them lose sight of each other but they do not give up their search for one another, and never resign themselves to the fate intended for them. They fall victims to intrigues but they resist seduction and corruption by members of the upper classes. This only brings them closer together and after they have found each other again in Berlin they finally consummate their love. Ulrike becomes pregnant and gives birth to a boy who, however, dies only two days later. Theirs had still been a kind of puppy love devoid of any higher purpose and sense of responsibility. Herrmann had made quite a bit of money gambling, and, in Rousseauan exuberance, he buys a small farm where, in his ecstatic words, 'Wir wollen ganz werden, wozu die Natur den Menschen bestimmte - den Acker bauen und uns lieben!' ${ }^{21}$ They defy society by living together as husband and wife, without the blessing of either church or state. They had experienced city life and now they live 
in the country, encountering, here as there, good as well as corrupt people. Wezel makes no distinction between environments, only between human beings. What counts exclusively is what people make of themselves, that they get to know themselves, overcome their weaknesses, and make a contribution to, and work for, the common good.

Herrmann and Ulrike, the two young enthusiasts, have not reached that point yet. They go bankrupt on their miniature Clarens and are separated once more. After the death of their child, Herrmann had vowed not to be intimate with Ulrike again until he can give her his name in marriage, and that can happen only after he has made something of himself. With the same determination Ulrike rejects any attempt to force her into marriage befitting her social standing. In the preface to Part One of his Robinson Krusoe (1779) Wezel programmatically stated what would be the theme of Herrmann und Ulrike, the novel to appear a year later. While the educator should develop 'alle Kräfte in dem besten Ebenmaße, so sehr es die persönliche Beschaffenheit und politische Lage bei einem jeden Subjekte zulassen,' the writer may contribute his share toward that end by writing a book,

das die Menschen von der Passivität zur Tätigkeit hinzieht.... Es muß ein Buch sein, das an Einbildungskraft, Witz, Verstand und Dichtergeist allen die Waage hält, die die Empfindsamkeit ausgebreitet haben; das ein Beispiel großer, edler, aufstrebender Tätigkeit enthält, wie sie jeder Jüngling nachahmen kann; das die Triebfeder der menschlichen Größe, die Ehre, anspannt; ... ein Charakter, aus den zwei Hauptelementen einer großen Seele, aus hoher Denkungsart und gefühlvollem Herze, zusammengesetzt, ohne die mindeste idealische Vollkommenheit, mit Schwachheiten und Gebrechen beladen, aber eine Seele voll Gleichgewicht; dieser Charakter muß durch eine Reihe von wahrscheinlichen Begebenheiten ohne alle Abenteuerlichkeit hindurchgeführt werden, immer stolpern, oft durch die Übertreibung seiner guten Eigenschaften fallen, dem Untergange und sogar dem Verbrechen sich dadurch nähern ... und doch mit unerschütterlichem Ausharren zu seinem letzten Zwecke hindurchdringen zu dem Zwecke, durch nützliche Geschäftigkeit auf einen beträchtlichen Teil seiner Nebenmenschen auf eine Art zu wirken, wie sie in unsrer Welt und bei unsrer Verfassung möglich ist. Nur ein solches Buch, aus unsrer gegenwärtigen Welt geschöpft, das uns Sitten, Leidenschaften, Menschen und Handlungen mit ihren Bewegungsgründen nicht nach moralischen Grundsätzen, sondern aus der Erfahrung darstellt ... und jungen Leuten eine Menschenkenntnis verschafft, die sie später mit ihrem Schaden durch eigne Erfahrung erwürben; das die Tugend nicht wie eine Feenkönigin und das Laster nicht wie einen Teufel malt, 
sondern jene als ein schwaches, gebrechliches, artiges, aber zärtliches Weibchen und dieses wie einen gleißenden Betrüger, der Gewalt braucht, wo keine List hilft - nur ein solches auf den Ton der wirklichen Welt gestimmtes Buch, sage ich, kann den erschlafften Nerven der Seele eine andre Spannung allmählich geben, insofern dies ein Buch vermag. ${ }^{22}$

When Herrmann and Ulrike have experienced and shared high and low points in life in the manner set forth above, when they have become 'aus Liebe tätig,' they are finally worthy of being joined in marriage as equal partners. This is diametrically opposed to the position Rousseau holds in La Nouvelle Héloise. Christine Touaillon succinctly summarizes Rousseau's view of women when she states that Sophie La Roche, in her efforts to find her own position as a woman and writer, got to know Rousseau as

den entschiedensten Gegner jeder Erweiterung der Frauenrechte.... Er forderte von der Frau Anmut, Empfänglichkeit, Schwäche und Unterwürfigkeit, während er Kraft, Tatendrang, Stärke und Willen als Grundeigenschaften des echten Mannes ansah. Die Fähigkeit der Frau, dem Manne zu gefallen, erschöpft für ihn restlos ihre Bestimmung; ihre Bildung und Erziehung machte er von dem Nutzen abhängig, welchen der Mann daraus ziehen konnte und die geschlechtliche Moral der Frau wurde von einem ganz unvergleichlich strengeren Standpunkte angesehen als jene des Mannes. Rousseaus scharfe Formulierung der männlichen Ansprüche an die Frau beherrschte länger als eine Generation hindurch die deutsche Literatur zur Frauenfrage. ${ }^{23}$

Wezel envisions social change neither through violent revolution nor through escape into an ideal and entirely unrealistic utopia, as represented by Rousseau's Clarens. He obviously wishes for a reform of society through meaningful cooperation between a self-confident and emancipated bourgeoisie and a truly enlightened aristocracy, as personified by the prince whom Herrmann serves toward the end of the novel in a highly respected and responsible capacity. In order to pacify Ulrike's family who still demand that she marry within her own class, the prince offers Herrmann 'den Adel.' His reply to the prince:

'Wenn Eu. Durchl. meine Dienste in einem höhern Stande angenehmer sind, so nehme ich das Geschenk mit Freude und Dank an: wo nicht, so verlange ich keinen Vorzug, der weder mein Verdienst noch Thre Gnade vergrößert.' 'Bravo!' 
sagte der Fürst und klopfte ihm auf die Schulter. 'Ich schätze den Mann von Verdienst; der Stand gilt mir gleich: es mag bleiben, wie es ist!' ${ }^{24}$

Wezel thus did write the first novel about bourgeois emancipation in German literature. He did suceed, as he intended in the preface to Herrmann und Ulrike, in raising the novel 'aus der Verachtung' and bringing it 'zur Vollkommenheit,' by utilizing and combining biographical and comical elements. Thus, in his words, 'würde die wahre bürgerliche Epopöe entstehen, was eigentlich der Roman sein soll. ${ }^{25}$

\author{
ALBERT R. SCHMITT \\ Emeritus, Brown University
}

\title{
Notes
}

1 For a recent example of ignoring Wezel see Dennis F. Mahoney, Der Roman der Goethezeit (1774-1829), Sammlung Metzler Band 241 (Stuttgart, 1988), where Wezel is mentioned only in connection with the as yet speculative theory that he may have been the author of Nachtwachen. Mahoney refers to Wezel merely as 'Verfasser von satirischen Romanen wie "Tobias Knaut" (1773-1776) und "Belphegor" (1776), der seit 1785 keinen Verleger für seine Schriften mehr finden konnte...' (117).

2 On the highly controversial relationship between Wezel and Wieland see Albert R. Schmitt, 'Wezel und Wieland,' in Christoph Martin Wieland: Nordamerikanische Forschungsbeiträge zur 250. Wiederkehr seines Geburtstages 1983, ed. Hansjörg Schelle (Tübingen: Niemeyer, 1984), 251-75. For a recent look at the 'realist' Wezel see Karl-Heinz Meyer, 'Bemerkungen über den reiselustigen Herrn Wezel,' in Sehen und Beschreiben: Europäische Reisen im 18. und frühen 19. Jahrhundert, ed. Wolfgang Griep, Eutiner Forschungen, vol. 1 (1991), 320-3.

3 Walter Urbanek, ed., steinmetzzeichen im laub: deutsche lyrik der gegenwart, texte band 17 (Bamberg: C.C. Buchner, 1964), 49.

4 Siegfried Lenz, Beziehungen: Ansichten und Bekenntnisse zur Literatur (Hamburg: Hoffmann \& Campe, 1970), 282.

5 Helfrich Peter Sturz, Die besten Schriften, zweiter Theil, Familienbibliothek der Deutschen Classiker (...) Zweiundzwanzigster Band (Hildburghausen $u$. Amsterdam: Bibliogr. Inst., 1842), 38, 39-40. I would also like to make reference to the fascinating review essay by Moses Mendelssohn, 'Über Rousseaus Neue Héloise,' in Briefe, die neueste Literatur betreffend, Brief 166-70, Berlin, Jahrgang 1761. The review essay is reprinted and easily accessible in Meister der deutschen Kritik, I: von Gottsched zu Hegel 1730-1830, ed. Gerhard F. Hering, dtv dokumente 18 (München: dtv, 1961), 59-74.

6 Johann Karl Wezel, Herrmann und Ulrike. Ein komischer Roman, Gerhard Steiner, ed. (Leipzig: Insel, 1980), 830; in the following cited as $\mathrm{HU}$. 
7 Pädagogische Unterhandlungen, Herausgegeben von dem Dessauischen Erziehungs-Institut. Zweytes Jahr. Erstes Quartal (Dessau, 1778), 3-101; here p. 9; in the following cited as $P U$.

$8 \mathrm{PU}, 10$.

$9 \mathrm{PU}, 11$.

$10 \mathrm{PU}, 12$.

$11 P U, 20$. Wezel's views on education await investigation and analysis since they would shed new light on his oeuvre in many respects.

12 This remark got Wezel in deep trouble with the Leipzig censor. For an excellent analysis of Wezel's Robinson see Anneliese Klingenberg's 'Nachwort' to her ed. of Johann Karl Wezel, Robinson Krusoe (Berlin: Rütten \& Loening, 1979), here pp. 273-4; in the following cited as $R K$.

$13 R K, \mathrm{II}, 127$.

$14 R K$, II, 127.

15 Phillip S. McKnight, The Novels of Johann Karl Wezel: Satire, Realism and Social Criticism in Late 18th Century Literature, New York University Ottendorfer Series, Neue Folge Band 14 (Bern: Peter Lang, 1981); Thilo Joerger, Roman und Emanzipation: Johann Karl Wezels 'bürgerliche Epopee,' Stuttgarter Arbeiten zur Germanistik Nr. 88 (Stuttgart: Akad. Vlg. Hans-Dieter Heinz, 1981); and Anneliese Klingenberg, 'Wezels Lebensgeschichte Tobias Knauts des Weisen, sonst der Stammler genannt,' in Weimarer Beiträge 35, no. 3 (1989), 430-49.

16 A. Klingenberg, s. fn. 15, 434.

17 In the book edition of the novel (1781) Wieland omitted the subtitle.

18 Walter Dietze, 'Wezels Belphegor - ein deutscher Candide,' in Wissenschaftliche Zeitschrift der Karl-Marx-Universität Leipzig, Gesellschafts- und Sprachwissenschaftliche Reihe, 14, no. 4 (1965), 771-96. Reprinted in Walter Dietze, Erbe und Gegenwart: Aufsätze zur vergleichenden Literaturwissenschaft (Berlin u. Weimar: Aufbau-Vlg., 1972), 135-92.

19 Th. Joerger, s. fn. 15, p. 164.

20 Tinian, one of the Mariana Islands; the irony of history would have it that Saint-Preux's idyllic island became the place where the atomic bombs were assembled that were dropped on Hiroshima and Nagasaki on Aug. 6 and 9, 1945.

$21 H U, 652$.

$22 R K, \mathrm{I}, 8-9$.

23 Christine Touaillon, Der deutsche Frauenroman des 18. Jahrhunderts (Wien u. Leipzig: Wilh. Braumüller, Universitäts-Verlagsbuchhdlg., 1919), 196.

$24 \mathrm{HU}, 804$.

$25 \mathrm{HU}, 5-6$. 